\title{
Hidden Danger Behind Financial Crisis in Emerging Markets
}

\author{
Shiyuan Yang ${ }^{1, *}$ \\ ${ }^{1}$ School of Finance, Capital University of Economics and Business, Beijing 100071, People's Republic of China \\ ${ }^{*}$ Corresponding author. Email: sherry_yang31@163.com
}

\begin{abstract}
Under the circumstance of financial integration, the spillover effect of financial crisis has gradually evolved from regions to worldwide. Plus, the outbreak of Covid-19 has accelerated the social and economic polarization. In general risk management research, countries with high debt defaulting risk were more likely to be attacked by financial crisis among emerging markets. Taking Argentina and Turkey as examples, this paper uncovered that sovereign currency strength is the original cause that drives emerging markets frequently exposed to financial risk. Accordingly the author puts forward suggestions to contain the risks in post epidemic era.
\end{abstract}

Keywords: Financial crisis, Sovereign currency, Emerging market.

\section{INTRODUCTION}

Financial crisis contagion refers to a phenomenon that the outbreak of economic crisis in one nation can attack other nations' economy in a multiplier effect, which consequently results in greater volatility to more regions even to the whole world. In earlier researches, high ratio of external debt was the most reasonable characteristics that considered as the cause of such crisis contagion [1]. However, what made these countries carry such a debt burden? Is it the result of the world economic system or the potential dangerous factors under their economy development? Besides, a Black Swan event heavily did damage to all countries in 2020. How will the Covid-19 epidemic strike emerging markets? What phenomenon could be recognized as a signal to avoid being involved into financial crisis as the economy recovers? Hence, it is of necessity to recognize the potential risk under liberal financial market relations especially after this global public health accident.

As far as economies of G20 members are concerned, 11 emerging markets can be divided into three groups based on debt defaulting risks [2]. Countries in first category like Argentina, Brazil, South Africa, India and Mexico are mostly enabled to cope with fiscal imbalance and current account deficit. In particular, Argentina became the first country to go bankrupt due to the Covid-19 all over the world. While for Turkey, Saudi Arabia and
Indonesia, a scale of current surplus and relatively sufficient domestic savings provide them with flexibility to relieve the debt burden. In the third category, China and Russia basically have little default risk. Therefore, this paper picked one from each of the first two groups (Argentina and Turkey) as representatives to analyze the possible factors contribute to fluctuations in emerging economy. The study can be the basis for further researches regarding financial risk in emerging market countries in the post epidemic era.

\section{ANALYSIS}

\subsection{Case 1: Argentina}

Historically speaking, Argentina had a weak credit foundation among international capital markets for a long time as it has undergone eight sovereign defaults since the independence in 1816, most recently in 2014. In 2020, the outbreak of Covid-19 has weighed heavily on its economic downturn. According to data released by Argentina's Ministry of Economy, the federal government's total debt was about \$323.4 billion by March 20, 2020. One month later on 17 April, Argentina's Ministry of Economy announced a debt restructuring programme. Considering of its heavy debt burden and high balance-of-payments deficits, Argentina's Creditor Committee rejected the government's debt 
restructuring proposal on April 20th, which meant Argentina officially went bankrupt.

\subsubsection{Huge Debt Hinders Economic Development}

The precarious situation under Argentina's economic system basically originates from its large scale of external debt and the excessive probability of debt defaulting. Argentina has much suffered from sovereign debt and therefore, in the first half of 2020, the government called for debt restructuring. The reasons behind Argentina's huge debt are as follows.

Compared to average level over the world, Argentina always attaches excessive importance to civil service, which gradually resulted in huge but unnecessary expenditure. In 2018, the number of civil servants in Argentina have already reached nearly $60 \%$ of its country's population while the average salary of governmental officials in Argentina's Public Revenue Authority was as high as 4100,000 pesos (about 4,000 US dollars) [3]. A large group of public functionaries took up the country's vast financial resources. At the same time, high salaries and generous benefits make public officials reluctant to change the abnormal focus of expenditure, which would finally exacerbate its redundant debt and unbalanced debt structure.
As a country with high recognition in welfare, a large scale of Argentina government's spending lie in social redistribution. The distorted expenditure structure constrained government's investment on infrastructure construction, which adds more pressure on its economic balance. In order to meet the national fiscal equilibrium, Argentina's government had to raise its corporate taxes to ensure fiscal revenues. This abnormal welfare system eventually leads to a contradictory situation that high welfare and high Gini coefficient exist in one country. Argentina has become a country with high welfare spending but still suffers from fragile economy system even economic crises.

As analyzed above, high social welfare leads to high taxes. As shown in "Figure 1", the gap between Argentina's tax revenue (grey line) and the general government's spending (blue line) was widening year by year. In the face of decreasing taxation, the government can only continuously raise the tax rate in order to maintain the daily fiscal balance. According to the statistics in Business Insider (2016), Argentina total tax rate $(137.3 \%)$ ranks first among 27 countries. While compared to regions with same high welfare system, French total tax rate $(66.6 \%)$ is less than half of that in Argentina [4]. Tax rate increase brings about local currency inflation which would disappoint domestic investment and in turn have an adverse effect on economic growth.

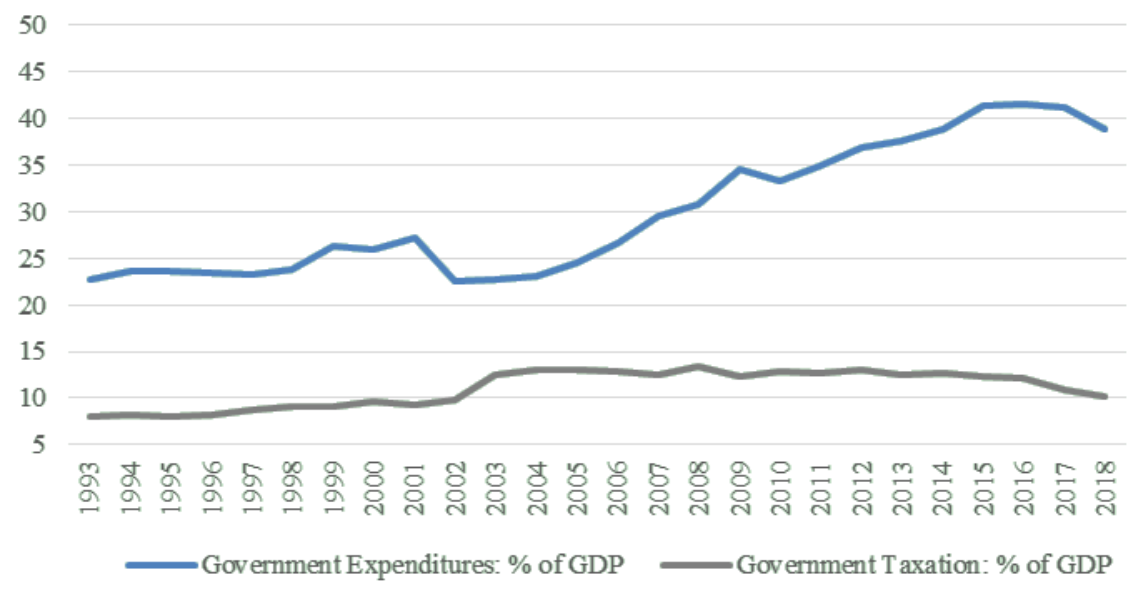

Figure 1 Government Expenditures and Taxation in \% of GDP in Argentina (1993-2018) (Source: World Bank, Wind).

\subsubsection{Single Export Structure Leads to BOP Instability}

Argentina main exports sources lie in agriculture, which closely bonds its economy growth with changeable factors like unpredictable climate conditions. The continued weakening agricultural prices further exacerbate the instability of Argentina's balance-of-payments. At the same time, Argentina's government implemented long-term import substitution policies aiming for local trade protection, which turned out to be a hidden trouble since it would 
waver the status of its primary industry and finally weaken Argentina's export competitiveness in global trade.

\subsubsection{Economic Dollarization Threatens Currency Sovereignty}

In 2002, Argentina abandoned the currency broad system in favor of a crawling peg. Over the next 15 years, peso depreciated slowly against dollar and the exchange rate remained relatively stable. Since 2017, Argentine peso has accelerated its depreciation while the rise of international protectionism also restricted Argentina's trade volume. To be worse, Covid-19 in 2020 largely shrank the international market demand for the primary export products from Argentina. Lack of export competitiveness led Argentina to a serious deficit in the balance of payments, and peso was sharply depreciated. The serious inflation exacerbated the people's distrust of Argentine peso, in order to avoid the possible devaluation of peso, the US dollar has gradually become Argentina's common settlement instrument, which did threaten the status of sovereignty currency and would bring great instability to Argentina's economy.

\subsection{Case 2: Turkey}

\subsubsection{Heavy Debt Dependency}

The ratio of external debt to GDP(GNI) always serve as the main international indicators that generally measure financial system's debt pressure as well as its defaulting risk. According to previous research, the internationally recognized "line level" standard is $20 \%$. If one countries' indicator value exceeds "the red line", it is necessary to send out an early warning signal concerning debt security to form a response measure in time. In "Figure 2", it is clearly presented that those emerging markets like Argentina (62.20\%), Turkey $(57.10 \%)$, South Africa $(52.70 \%)$ and Russia Federation $(31.80 \%)$ both highly exceed the internationally recognized safe line (red line) while India (19.74\%) is reaching the edge of danger. Central banks' external debt, reflecting high defaulting short-term risk, always serve as a pessimistic signal for the possible breakout of credit collapse. Large-scale debt threatens the independence of Turkey's financial system, which is also widespread in emerging markets.

Extemal debt stocks (\% of GDP)

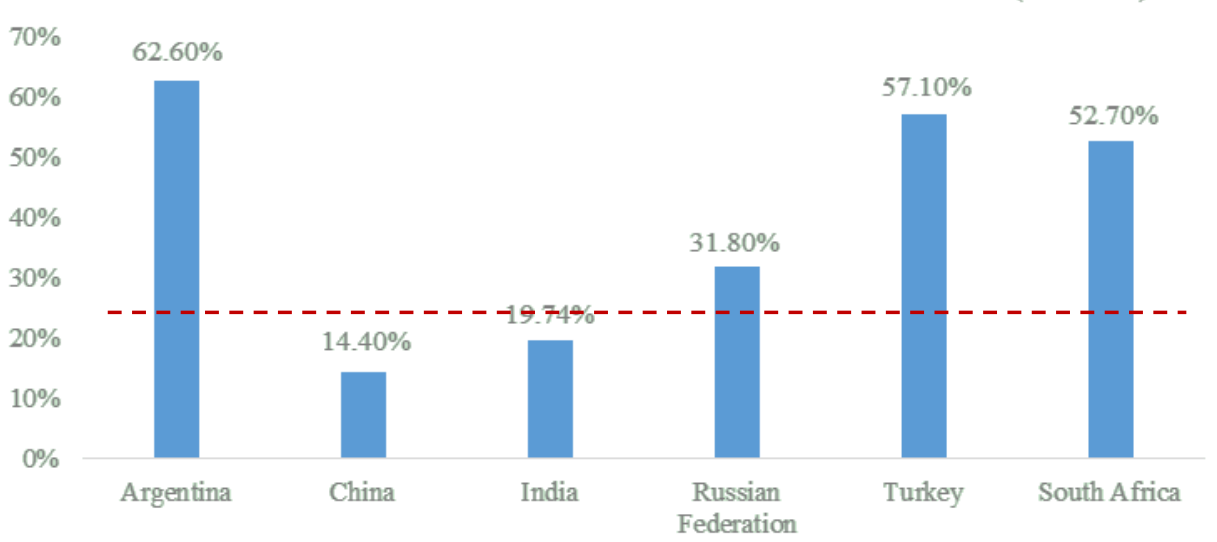

Figure 2 Ratio of external debt to GDP (\%) (Source: World Bank).

For debt structure, a vast majority of emerging markets' debt are dollar-denominated, as a result of the relatively poor sovereignty credit and the low credit worth of their local currencies. After the financial crisis broke out in 2008, mature markets such as the United States, Europe and Japan adopted easing monetary policies for economy stimulating. By applying lower interest rate, developed countries can reduce lending cost for emerging markets and accordingly accelerated the expansion of its capital controls, which would pushed up the size of emerging markets' external debt.

\subsubsection{Imbalance Current Account Cannot Afford the Financing Demand}

Long-term current account deficits would gradually impel one country more relying on foreign capital inflows to meet the need of foreign exchange expansion. However, the imbalance between its increasing demand and the depletion of foreign 
exchange reserve will lead its local currencies under downward pressure. According to "Figure 3", Turkey had suffered from current account deficits for a long time. Before 2002, Turkey's current account relative to GDP remained at a roughly balanced level within $4 \%$ to $+4 \%$ with fluctuations (average volatility as high as 63.84\%). During 2002-2015, the current account values are negative and presented in a downward trend, which meant that current account deficits kept widening, reaching $-4.7 \%$ of GDP on average. Although the deficit from 2011 to 2015 narrowed to $-1.1 \%$, it has expanded to $-7.9 \%$ in the first quarter of 2018.

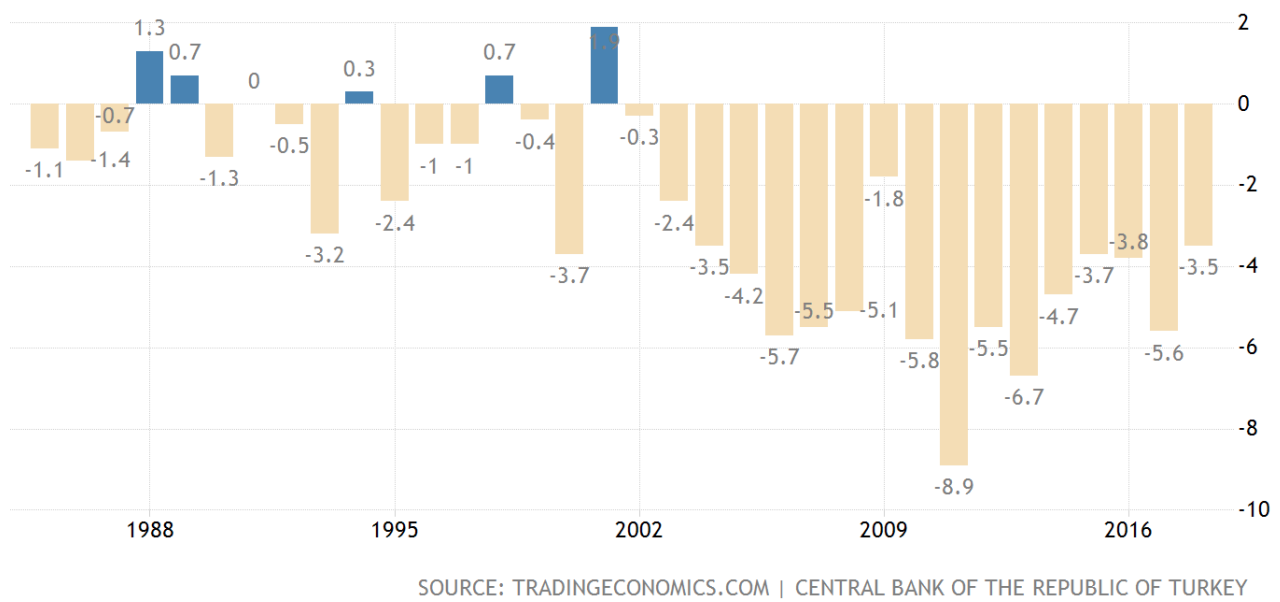

Figure 3 Turkey's current account deficits relative to GDP (\%).

Economies in current account deficits will enter a vicious cycle of sovereign currencies continuously weakening since they must keep carrying out largescale foreign exchange financing, which is concluded in "Figure 4". That means that for emerging markets, capital account opening as well as sufficient foreign exchange reserves act as the key basis during one country's economic development. Once capital flows are too heavy for these originally weak currency account to achieve balancing, it would accumulate more financial risks that leads to further economic fluctuations and instability.

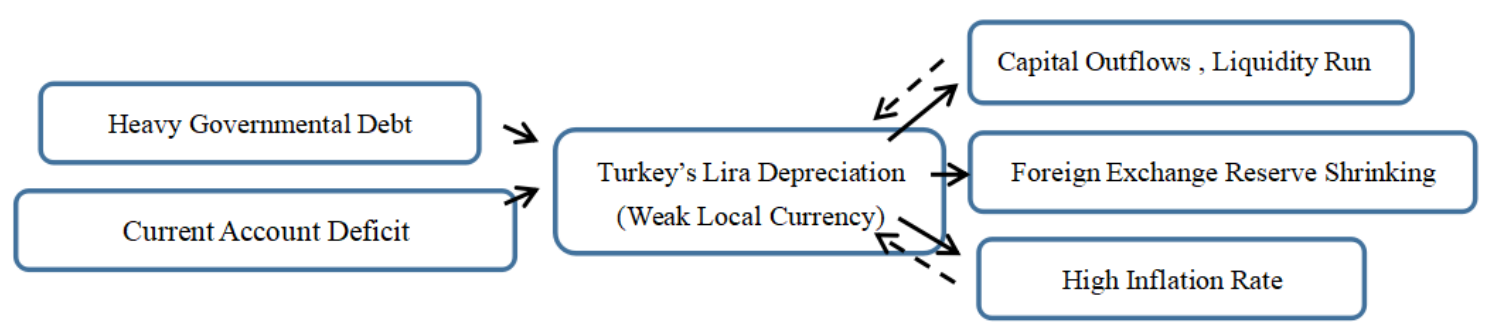

Figure 4 Linkage Theory of Financial Crisis in Turkey.

\subsection{Causes of Financial Crisis in Emerging Markets}

GDP and DINIW (an index showing US dollars' strength).

\subsubsection{External Reasons}

In two cases, dollar-dominated debt both acted as the last straw to the outbreak of financial crises in emerging markets. Too much debt will contribute to one nation's excessive dependence on dollar. Consequently, the development of economy will also be constrained by the US monetary policy, which could be proved by the connection between world 


\section{Latin American Debt Crisis $\quad$ Asian Debt Crisis}

Turkish Debt Crisis

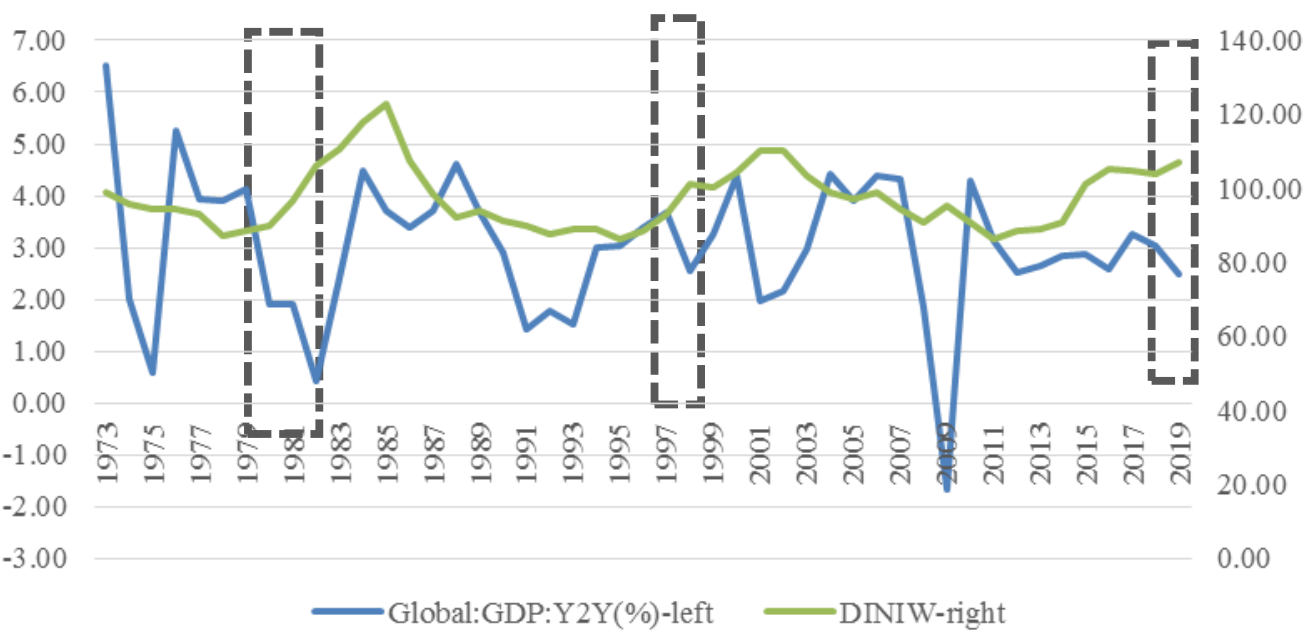

Figure 5 Emerging market financial crisis eruptions as global economy slumps and dollar appreciation (Source: National Foreign Exchange Management Bureau, Wind).

As shown in the "Figure 5", the dotted box shows the time span of major financial crises in emerging economies. It is the interval forming by negative slope of blue line and positive slope of gray line that mostly lie in the eruption of emerging markets' financial crises.

When the global economy is in recession but the US is implementing quantitative easing policy, emerging markets are more likely to be suffered from fiscal imbalance along with local currency depreciation. Financial risk would diffuse from a weak coin in one country but finally brings a crisis at least into a regional recession by global capital flow.
Besides, based on rational expectation theory, crises contagion will destabilize the country's economy and shock the investment predictions on the economic growth, which would promote the crossborder capital outflow. Tracing back on history, we shall keep an eye on the uncertainty in global financial markets measured by VIX index. In "Figure 6", moments appears an apparent peaks are generally coincide with the time transnational capital flows out from emerging market countries into developed countries especially the United States. This corresponding relationship between capital outflow and financial system's uncertainty also improve persuasiveness for the crisis contagion mechanism in emerging markets.

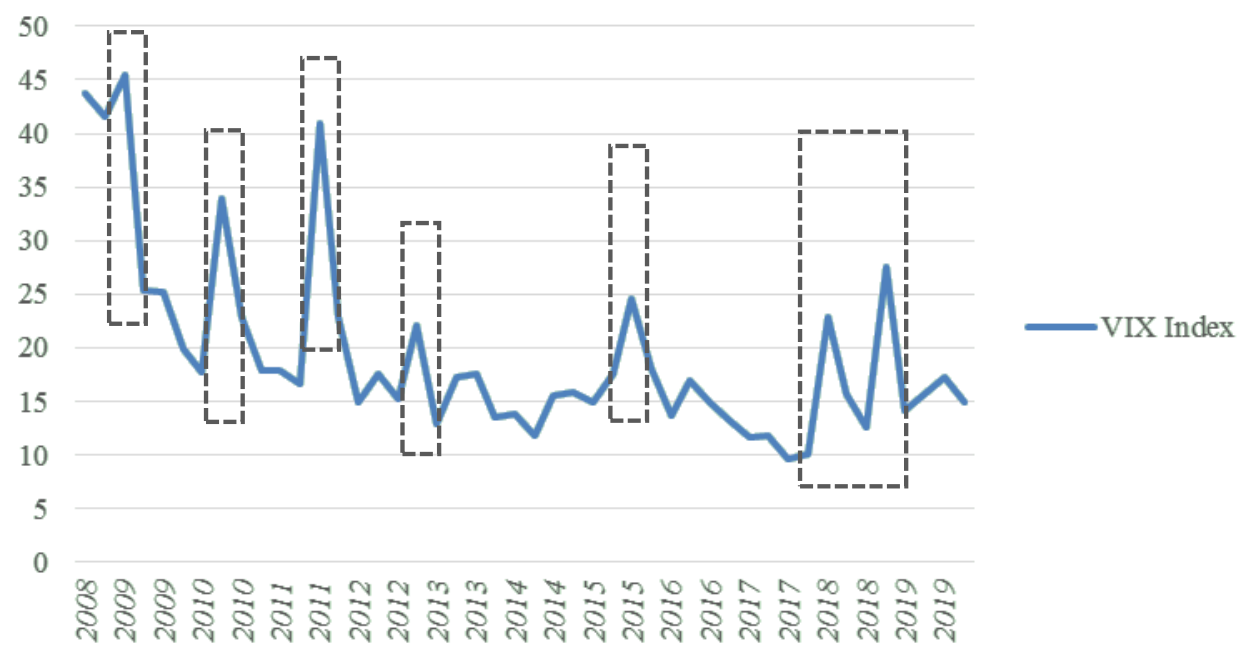

Figure 6 Uncertainty in Global Financial Markets 2008-2019 (Source: CBOE, Wind). 


\subsubsection{Internal Reasons}

After World War II, by constructing global value chains, developed countries play a major role in the contribution to world economic growth. They are at both ends of the smile curve, which demonstrated that developed countries occupy advanced technology and a large portion of goods competitiveness. On the contrast, emerging market economies are at the middle of the curve, providing natural resources or engaging in primary production. This smile curve indicates emerging countries can leave little wave to the global market while at the same time highly depend on developed countries especially presented as trade negotiation or even external debt.

As shown in "Figure 7" and " Figure 8", real GDP in Argentina and Turkey are both positively correlated with export revenue growth. However, the exports growth comes from natural advantages in emerging markets, which will eventually lead to uneven economic development pattern. For example, Argentina used to implement the import substitution strategy to promote the domestic industry. Under the protection of the local government, domestic industrial sector gradually lost its competitiveness in international trade, which is definitely an unsustainable developing road.

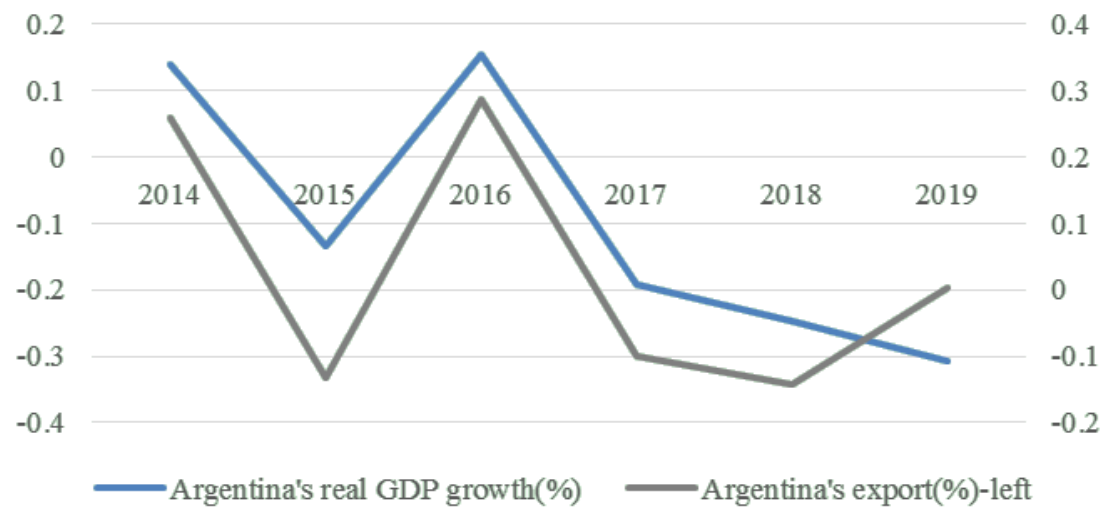

Figure 7 High Consistency of GDP and Export revenue in Argentina(2014-2020).

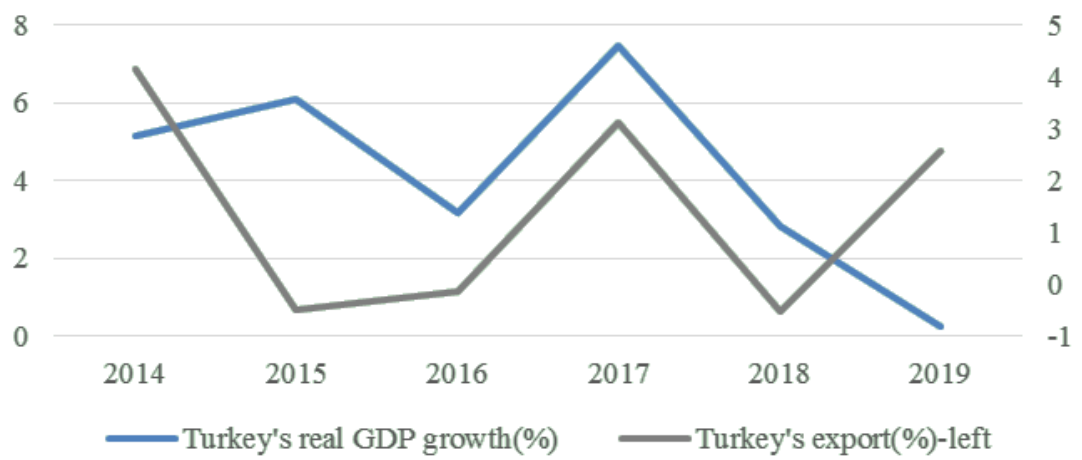

Figure 8 High Consistency of GDP and Export revenue in Turkey (2014-2020).

\section{CONCLUSION}

The crisis in emerging market economies is the result of a combination of both internal and external factor. When most countries are facing an economic slowdown along while dollar is appreciating, emerging markets are prone to currency depreciation pressure or even financial crisis. External debts seem to be blame for the start of financial crisis among emerging markets but the real causes are the loss of trade autonomy resulting from the market vulnerability itself, which superficially shows a linkage relation but essentially an inevitable phenomenon.

Global economy is recovering from recession after the shock of Covid-19. According to the world economic outlook report by the International Monetary Fund (IMF) issued in October, the growth 
rate of the global economy will drop to $4.4 \%$ by the end of 2020, among which emerging markets and developing economies are expected to shrink to $3.3 \%$ [9]. Emerging market countries' inability to gain external financing is the source of economic vulnerability, which sharply decreases the flexibility to adjust its capital flows when facing economic fluctuations. Consequently, how much emerging market economies will be attacked in the face of external shocks depends on its currency strength. In March 2020, four circuit breakers in the U.S. stock market triggered a devaluation of exchange rate and a serious capital outflow trend in emerging markets. Affected by the rise of U.S. dollar index, emerging economies with high trade dependence, such as Turkey, Argentina and other countries, will be more likely to undergo economic downturn and currency depreciation pressure.

For further development, timely measures should be taken to maintain the independence of sovereign currency and economy operation especially during post epidemic era. It seems like a long-term structured reformation but would fundamentally improve emerging countries' autonomy while facing abnormal fluctuations as well as financial contagion shock within capital flows.

\section{AUTHORS' CONTRIBUTIONS}

This paper is independently completed by Shiyuan Yang.

\section{ACKNOWLEDGMENTS}

I deeply appreciate all those who have helped me during the writing of this thesis. I gratefully acknowledge the help of Professor Leven. I do appreciate his patience, encouragement, and professional instructions during the academic courses and thesis writing. My gratitude also extends to all the teachers who have taken the time to review the essay and made valuable suggestions. Last but not the least, I would like to express my gratitude to the contribution made in various ways by my friends.

\section{REFERENCES}

[1] Liu Jing, Yu Wei, Li Yu. Study on the Construction of Early Warning Models of Sovereign Debt Crisis - Based on the Study of the External Debt Risks of the Four Latin American Countries, Business Economy, 2021 (03): 159-161 plus 169.
[2] Jiang Chung." Silver Country "Meets the Blue Dollar"-Warnings from the Dollarization of Argentina's Economy, 2020 (12): 92-96.

[3] Gaston Gelos, Jay Surti. The Growing Importance of Financial Spillovers from Emerging Market Economies.

[4] Karl P. Sauvant, Wolfgang A. Maschek, Geraldine McAllister. Foreign Direct Investment by Emerging Market Multinational Enterprises, the Impact of the Financial Crisis and Recession, and Challenges Ahead [J]. Journal of WTO and China, 2011, 1(01):3-30.

[5] Adrian Alter, Selim Elekdag. Emerging market corporate leverage and global financial conditions [J]. Journal of Corporate Finance, 2020 .

[6] Gu Xinyuan, Qin Hongjun. The Formation and Prevention of Financial Risks in the Context of Economic Transformation and Upgrading Based on the Comparative Analysis of Mexico, South Korea and Argentina, Economic Research Guide, 2019, (19): 115-117.

[7] Li Zhao. The Currency Crisis in Emerging Markets and its Enlightenment to China Taking Turkey, Argentina, for example, J. Heilongjiang Finance, 2019 (05): 20-22.

[8] Pınar Kaya Soylu, Bülent Güloğlu. Financial contagion and flight to quality between emerging markets and U.S. bond market [J]. North American Journal of Economics and Finance, 2019, 50.

[9] Zhong Hong, Liu Jialin. Characteristics and Trends of Cross-Border Capital Flows in Emerging Markets Under the Impact of the Epidemic, 2021 (01): 15-20. 